\title{
Millennials and their attitudes to the corporate social responsibility of global brands: The case study of Slovak Republic
}

\author{
Margareta Nadanyiova ${ }^{1, *}$ \\ ${ }^{1}$ University of Zilina, Faculty of Operation and Economics of Transport and Communications, \\ Department of Economics, Univerzitna 1, 01026 Zilina, Slovak Republic
}

\begin{abstract}
Research background: In addition to their economic activities, global brands applying the concept of corporate social responsibility are also focused on social and environmental aspects. At the same time, they emphasize that these interests are not in conflict, on the contrary, they can work together to increase the efficiency of brand strategy. The basis for the application of corporate social responsibility is the fact that customers are becoming more and more sensitive to other activities of the brand and not just to sales. Especially, one generation of consumers, Millennials, is considered to be the driving force behind the demand for socially responsible brands and products.

Purpose of the article: The main aim of the paper is to determine the attitudes of Millennials to the corporate social responsibility of global brands. This includes providing the theoretical background and analysis of the corporate social responsibility from the viewpoint of Slovak and foreign authors.

Methods: General scientific methods were applied for the processing of the data as well as mathematical-statistical methods to evaluate the data collated from the results of the questionnaire survey and to statistical hypothesis testing. The important source for secondary data was scientific researches, annual companies reports, statistical databases, published professional publications. In order to found out the attitudes of Millennials to the corporate social responsibility of global brands, a questionnaire survey was conducted among Slovak consumers.

Findings \& Value added: Based on the analysis and results of the questionnaire survey, benefits of the application of corporate social responsibility in the marketing strategy of global brands are highlighted such as gaining competitive advantage, increasing the brand value and improving brand image.
\end{abstract}

Keywords: corporate social responsibility; Millennials; global brands; customers; competitive advantage;

\footnotetext{
*Corresponding author: margareta.nadanyiova@,fpedas.uniza.sk
} 
JEL Classification: $M 14 ; Q 01 ; Q 56 ; F 60$;

\section{Introduction}

The concept of corporate social responsibility is based on the foundations of ethics and, as a result of the negative effects of globalization (greater environmental pollution, carbon footprint, relocation of production to developing countries with cheaper labour), it is being talked about very intense. Today, more and more companies are beginning to realize the connection with profit and adherence to ethical principles, which can represent a great competitive advantage in a highly competitive market. Companies are aware that their longterm success depends on the surrounding communities, and it is therefore in their interest to support these communities and invest in their development (Esses et al., 2021; Biro and Csete, 2020). No company can exist as a separate independent unit; it is always part of some larger unit that can influence and at the same time is influenced by it.

Corporate social responsibility requires compliance with a code of ethics, which is the starting point for all business partnerships. Companies strive for transparent behaviour and building long-term relationships with business partners based on trust and mutual respect. In the social field, respect for human rights, support for local communities and nongovernmental non-profit organizations or foundations, support for charitable and charitable events are key for socially responsible companies. They try to negatively affect the environment as little as possible within their business. They invest in the development of new technologies, conserve natural resources and seek to draw on energy from renewable sources in order to mitigate as much as possible the environmental impacts leading to climate change (Lizbetinova and Hitka, 2016; Podhorska et al, 2017). The raw materials needed for business are sought to be obtained in an environmentally friendly and ethical way. Taking these steps in the economic, social and environmental fields leads to sustainable business and the conservation of natural resources for future generations.

Based on the above, the corporate social responsibility can be linked to the social, political and environmental challenges of globalization, which affects the whole world . The corporate social responsibility can also influence the direction of globalization to some extent and can be considered as an integrative element of corporate management for (not only) global brands in order to achieve a competitive advantage and minimize risk (Wood, 1991).

One of the consumers' generations, so-called Millennials, is currently considered to be the driving force behind the demand for socially responsible brands and products. It is a generation that has already reached adulthood, and therefore it is economically active and increasingly important in the market of workforce as well as consumers (Bucic et al., 2012; Fry, 2016). It is often referred to as Internet generation with constant access to information and tremendous power on social networks (Wiedmer, 2015). A lot of research and studies claim that this is a generation educated in the field of CSR and thanks to their representation in the traditional market as well as the labour market with the power to require companies to be socially responsible (Nielsen, 2018). At the same time, however, several publications have reached the opposite conclusion - although the Millennials perceive CSR on a theoretical level as an important issue and should be interested in, they themselves do not show much interest in sustainable behaviour and as individuals do not contribute much to it (Hume, 2010; Schoolman et al., 2016). The main reason for focusing this generation is mainly its growing importance, the power of its impact on companies and the ambiguous results in determining their interest and involvement in CSR activities.

The generation of Millennials includes people born between about 1981 and 1997. Some authors, such as Lee and Kotler (2015), present a wider range of this generation, defined between 1980 and 2000. Approximately, this generation now represents 27\% of our planet's total population and is becoming of which the largest global generation of consumers in 
history (Anderson et al., 2018). It is therefore more than obvious that this is a group with significant purchasing power, whose needs and attitudes must not be neglected by companies and their marketers.

\section{Literature Review}

Corporate social responsibility is an extremely important element for brands that aim to be ethical and transparent in the eyes of their consumers (Horoszowski, 2016). The importance of this concept has grown even more in the past decade, both among companies and their customers. According to a PwC Global CEO study, more than $64 \%$ of CEOs worldwide are now increasing investment in corporate social responsibility projects, arguing that corporate social responsibility is not just a stand-alone program, but at the heart of their entire business (Horoszowski, 2016). Social and ethical issues are gaining increased public attention, which logically leads to great market pressure from customers and other stakeholders on the responsible behaviour of companies (Low, 2016).

The concept of corporate social responsibility has undergone development since the 1950 s, when this concept first came to the fore to the present day. In the 1950s, the prevailing view in the field of CSR was that social responsibility lies in the fact that companies and their managers internally monitor their activities without dependence on the coercive power of the state. The topic of corporate responsibility towards society and the idea of sustainable development began to emerge during the 1960s, and stakeholder theory first appeared in the 1970s. This theory emphasizes the interconnectedness of relationships between companies and their environment, i.e. customers, suppliers, employees, investors and communities. During the 1990s, the concept of CSR was then considered part of broader concepts.

The topic of corporate social responsibility currently consists of a large number of secondary topics, which include e.g. social responsibility, sustainable development, corporate ethics, corporate citizenship, Triple-bottom line; 3P concept (People, Profit, Planet), social philanthropy and corporate governance (Low, 2016).

Carroll (1979) described CSR as a comprehensive concept, which defined four dimensions of socially responsible corporate behaviour. These four dimensions include all the responsibilities of the company, such as economic responsibilities, legal responsibilities, ethical responsibilities, philantropic responsibilities.

Following this, Burke and Logsdon (1996) determined the strategic CSR dimensions necessary to achieve the business goals and create the business value - centrality, specificity, proactivity, visibility and voluntarism.

Based on several previous definitions, Dahlsrud (2008) has defined five basic aspects of CSR that have been repeated in these definitions, namely:

1. Environmental fields

2. Social fields

3. Economic fields

4. Stakeholders

5. Volunteering.

According to these and many others research publications (Chen and Gavious, 2015; European Commission, 2019), we can claim, that the significant and important feature of the CSR is the principle of volunteering. Companies also have to apply social, environmental, ethical, human rights and consumer concerns into their business operations in close collaboration with their stakeholders (European Commission, 2019).

The basis of the CSR concept as well as sustainable development lies in the issue of triple corporate responsibility, so called Triple Bottom Line (TBL) which includes three pillars of social responsibility of the company - environmental, economic and social (Elkington, 1998). 
This theory was modified to the widespread concept so called "3P" - People, Planet and Profit as an expression of corporate social, environmental and economic responsibility.

The attitudes of the Millennials generation and their shopping behaviour have already been researched by a number of authors. According to Moreno et al. (2017), Millennials represent a very attractive market group because they are a generation that has grown up in an environment where technology is a platform for personalization and immediate satisfaction of needs in all aspects of life. At the same time, for them, the shopping process is fun, and their loyalty to the brands they buy is relative. On the other hand, Millennials are more sensitive to price fluctuations much less loyal to brands than their predecessors (Taylor, 2019).

It is also quite evident that the Millennials generation, the group with the fastest growing purchasing power today, is a group with very clear values worldwide that is willing to invest its money in products that match their worldview (Landrum, 2017; Rudominer, 2017). This generation is fast becoming a more and more influential group with great market power. According to a Nielsen study (Nielsen, 2015), over 73\% of Millennials are willing to pay extra for a product or service from socially responsible companies and $81 \%$ of them expect their favourite companies to publicly emphasize their steps towards sustainability and the charitable projects in which these companies participate (Landrum, 2017).

Some authors (Anderson et al., 2018; Brown and Dacin, 1997) have concluded that positive CSR can strongly influence the preferences of consumers of this generation and play an important role in their decision-making process. In addition, Millennials are more proactive in finding information. Their purchasing decisions are therefore not only influenced by the passive receipt of information, e.g. from media and campaigns of individual companies. The Millennials show greater initiative, e.g. when reading product labels or examining the material from which the product or its packaging was made. In addition, this generation is aware of its influence. The Havas Prosumer Report (Havas Worldwide, 2013) found that $50 \%$ of millennials believe they have a greater impact on society as consumers than as voters. Determinants of the impact of CSR on Millennials' purchasing behaviour include authenticity, brand alignment with a given CSR initiative and the level of commitment to the initiative by the company (Taylor, 2019). At the same time, socially responsible companies attract not only customers from the Millennials generation, but also employees. The involvement in CSR activities in the company's strategy increases the attractiveness of the employer from the point of view of members of the Millennials generation (McGlone et al., 2011).

\section{Methods}

The main aim of the paper is to determine the attitudes of Millennials to the corporate social responsibility of global brands. This includes providing the theoretical background and analysis of the corporate social responsibility from the viewpoint of Slovak and foreign authors. The important source for secondary data was scientific researches, annual companies reports, statistical databases, published professional publications. In order to found out the attitudes of Millennials to the corporate social responsibility of global brands, a questionnaire survey was conducted among Slovak consumers. Based on the analysis and results of the questionnaire survey, benefits of the application of corporate social responsibility in the marketing strategy of global brands are highlighted such as gaining competitive advantage, increasing the brand value and improving brand image.

General scientific methods were applied for the processing of the data as well as mathematical-statistical methods to evaluate the data collated from the results of the questionnaire survey and to statistical hypothesis testing. 
The aim of the questionnaire survey was to analyse the attitudes of Millennials to the corporate social responsibility of global brands. The sample size was determined using the Sample Size Calculator that forms part of Creative Research Systems' survey software and which is provided as a public service. The calculator determines how many respondents need to be interviewed in order to get results that reflect the target population as precisely as possible. This is necessary to avoid any distortion in the survey information. The process requires a base file to work from, which in this case consisted of population data for the Slovak Republic, and in particular data on those born in 1981-1996. The confidence interval was set at $5 \%$, with a confidence level of $95 \%$. This means that for the questionnaire survey a $5 \%$ margin of error is assumed. The sample size calculated by the calculator was determined to be 384 respondents. In total, 625 respondents participated in the questionnaire survey.

The questionnaire survey was conducted in May 2021. The selection of the respondents in the sample set took place at random and was based on the number of Slovak inhabitants born in 1981-1996 that belong to Millennials. The quantitative assessment method was applied to the processing of the information obtained from the questionnaire survey. The data were processed empirically in the form of percentages, with additional written comments and comparisons.

In order to achieve the main aim of the article, based on the theoretical background and survey results, research hypotheses are formulated:

- Hypothesis 1: More than 50\% Millennials know the concept of CSR.

- Hypothesis 2: More than 50\% Millennials consider the use of CSR in the brand strategy to be a factor in improving global brand's image.

- Hypothesis 3: When making purchasing decisions, more than 50\% of Millennials prefer a global brand that behaves socially responsibly.

The marginal rate $50 \%$ was set as the expression of the simple majority (Macfie and Nufrio, 2006).

Statistical hypotheses testing is defined as a statement of the assumption of unknown parameters in the basic set, which is formulated as a statistical hypothesis and its validity is verified by statistical procedures based on selection characteristics. The role of statistical hypotheses testing is to decide whether to accept or reject the hypothesis regarding the basic set in accordance to the information from the available choice. In verification of the hypotheses, the methodology of statistical hypothesis testing consisting of the following steps was met (Rimarcik, 2007):

1. Formulation of the null hypothesis (H0).

2. Formulation of the alternative hypothesis (H1).

3. Determining the level of significance $(\alpha)$.

4. Calculation of test statistics and probability.

5. Decision.

The test statistic for hypotheses $1-3$ we calculated by using the method testing a single proportion by one-tailed testing because it is commonly used (Ruxton and Neuhauser, 2010; Lombardi and Hurlbert, 2009). Significance level $\alpha$ was determined at 0.05.

\section{Results}

Of the 625 respondents in the sample set, $380(61 \%)$ were female and $245(39 \%)$ were male. The results of the questionnaire survey show that $79 \%$ Millennials know the CSR concept. $71 \%$ respondents consider the involvement in social responsibility as a necessary part of global brands strategy. According to respondents, the most important benefits of implementation CSR in global brands strategy is improving brands image $(65 \%)$, gaining competitive advantage (49\%), increasing the brand value (45\%) and gaining the customers loyalty $(39 \%)$. The results of the questionnaire survey show that when making purchasing 
decisions, 66\% Millennials prefer brands that behave socially responsibly (applying the principles of economic, environmental and social responsibility).

To verify the statistical hypotheses $1-3$, we used the method testing a single proportion. Results of verification these statistical hypotheses are shown in Table 1.

Significance level $\alpha$ was determined at 0.05 . The test criteria were calculated according to:

$$
T=\frac{p-\pi_{0}}{\sqrt{\frac{\pi_{0 *\left(1-\pi_{0}\right)}}{n}}}
$$

By using the tables of the normalized normal distribution, we find the critical value for the right-tailed test (2) for hypotheses $1-3$.

$$
T>z_{2 \alpha}
$$

Table 1. Verification of statistical hypotheses

\begin{tabular}{|c|c|c|c|c|c|}
\hline $\begin{array}{c}\text { Calculation of the } \\
\text { sample } \\
\text { proportion: } \\
p=\frac{m}{n}\end{array}$ & $\begin{array}{c}\text { Satisfaction of the } \\
\text { condition }\end{array}$ & $\begin{array}{c}\text { Test } \\
\text { criteria }\end{array}$ & $\begin{array}{c}\text { Critical } \\
\text { field }\end{array}$ & Inequality & $\begin{array}{c}\text { Acceptance } \\
\text { or rejection } \\
\text { of the } \\
\text { hypothesis }\end{array}$ \\
\hline
\end{tabular}

\section{Hypothesis 1:}

$\mathrm{H}_{0}: 50 \%$ Millennials know the concept of CSR.

$\mathrm{H}_{1}$ : More than $50 \%$ Millennials know the concept of CSR.

\begin{tabular}{|c|c|c|c|c|c|}
\hline $\mathrm{p}=0.79$ & $156.25>9$ & 14.5 & 1.645 & $14.5>1.645$ & $\mathrm{H}_{0}$ rejected \\
\hline
\end{tabular}

Hypothesis 2:

$\mathrm{H}_{0}: 50 \%$ Millennials consider the use of CSR in the brand strategy to be a factor in improving global brand's image.

$\mathrm{H}_{1}$ : More than $50 \%$ Millennials consider the use of CSR in the brand strategy to be a factor in improving global brand's image.

\begin{tabular}{|c|c|c|c|c|c|}
\hline $\mathrm{p}=0.65$ & $156.25>9$ & 7.5 & 1.645 & $7.5>1.645$ & $\mathrm{H}_{0}$ rejected \\
\hline
\end{tabular}

\section{Hypothesis 3:}

$\mathrm{H}_{0}$ : When making purchasing decisions, $50 \%$ of Millennials prefer a global brand that behaves socially responsibly.

$\mathrm{H}_{1}$ : When making purchasing decisions, more than $50 \%$ of Millennials prefer a global brand that behaves socially responsibly.

\begin{tabular}{|l|c|c|c|c|c|}
\hline $\mathrm{p}=0.66$ & $156.25>9$ & 8 & 1.645 & $8>1.645$ & $\mathrm{H}_{0}$ rejected \\
\hline
\end{tabular}

Source: Own processing.

Table 1 shows, that in hypotheses $1-3$ the inequality applies, so we reject the hypothesis $\mathrm{H}_{0}$, i.e., accept the alternative hypothesis $\mathrm{H}_{1}$.

\section{Discussion}

Based on the analysis and survey results, it is obvious, that the majority of Millennials know the concept of CSR. They are aware of benefits which result from the implementation of CSR for companies, and thus most of them consider the use of CSR in the brand strategy to be a factor in improving global brand's image. In this reason, when making purchasing decisions, more than a half of Millennials consumers prefer a global brand that behaves socially responsibly.

When compare our survey results with previously realized research, we can find several identical characters. Millennials are actively involved in the process of achieving sustainable 
development of the whole society, especially they participated in socially responsible activities such as buying a product that brings benefits to society or the environment and substitute a previously preferred brand for another if its higher contribution to building sustainable development of society is demonstrated (Hume, 2010; Landrum, 2017; Nielsen, 2015; Nielsen, 2018; Schoolman et al., 2016).

It follows from the above mentioned, that Millennials declare their willingness to contribute to socially responsible activities, although this is mainly reflected secondarily in their purchasing preferences for socially responsible products. For Millennials, it is important to know whether their buying behaviour contributes to solve societal problems and help them meet their long-term sustainability commitments (Majerova, 2014; Moravcikova et al., 2017). In global, Millennials currently have a significant representation and thus form the predominant generation in both the consumer and labour markets. Although the situation in the Slovak Republic is relatively different than in the countries of Western Europe or the USA, Millennials nevertheless have a significant impact on both markets and require companies to behave socially responsibly and to become active creators of long-term social sustainability. For this reason, Millennials represent the target segment for the socially responsible global brands.

\section{Conclusions}

Based on the above as well as previous surveys, it is obvious, that Millennials show a greater interest in the environment, sustainable business and society, volunteering and donations than others generations, both from the point of view of employees and consumers. If the global company implements socially responsibly activities in its business strategy, it may be a more attractive employer and employee loyalty to it is growing. It will also attract more customers due to the growing interest of this group in socially responsible products and the socially responsible behaviour of global brands.

Millennials already have a significant presence and influence in the consumer market and is expected to be the predominant generation in these markets within a few years. Due to their position, they will shape these markets through their requirements. These conclusions proved the power and importance of the Millennials to influence the shape of the world, but the question is, what are their requirements.

The outcomes of the research provide the overview of the attitudes of Millennials to the corporate social responsibility of global brands, which can be considered as a main theoretical benefit of the article. It also provides space for further discussions on specific activities of corporate social responsibility of global brands in relation to Millennials as well as to others generational cohorts. It is obvious that Millennials represent the target group of the socially responsible global brands, because they prefer and buy products of the socially responsible brands. Additionally, mentioned generation consider the use of CSR in the brand strategy to be a factor in improving global brand's image, and when making purchasing decisions, the majority of them prefer a global brand that behaves socially responsibly. Thus, the survey results can have a significant application in practice, especially in predicting purchasing behavior based on attitudes of target segment. Based on this, the main managerial recommendation consists of the targeting on Millennials within socially responsible business strategy of global brands.

The issue of Millennials as a socially responsible generation of consumers has, therefore, the potential for deeper research in the future - both qualitatively and quantitatively. To obtain statistical relevance, it would be appropriate to investigate the findings of qualitative research quantitatively. For expanding knowledge and in order to gain a better overview in this issue, it would be appropriate to examine and compare the impact of CSR on buying behaviour of 
Millennials compare with Post-Millennials as another target segment of socially responsible brands, possibly with other generations.

\section{Acknowledgements}

This paper is a partial output of the project VEGA no. 1/0064/20: Behaviorism in a socially responsible communication strategy of enterprises.

\section{References}

1. Anderson, R., Dahlquist, S, \& Garver, M. (2018). Millennials' Purchasing Response to Firms' CSR Behavior. Marketing Management Journal, 28(1), 14-29.

2. Biro, K., \& Csete, M. S. (2020). Corporate social responsibility in agribusiness: climaterelated empirical findings from Hungary. Environment Development and Sustainability, 23(4), 5674-5694.

3. Brown, T. J., \& Dacin, P. A. (1997). The Company and the Product: Corporate Associations and Consumer Product Responses. Journal of Marketing, 61(1), 68-84.

4. Bucic, T., Harris, J., \& Arli, D. (2012). Ethical Consumers Among the Millennials: A Cross-National Study. Journal of Business Ethics, 110(1), 113-131.

5. Burke, L., Logsdon, J. M. (1996). How corporate social responsibility pays off. Long Range Planning, 29(4), 495-502.

6. Carroll, A. B. (1979). A three-dimensional conceptual model of corporate performance. Academy of management review, 4(4), 497-505.

7. Chen, E., Gavious, I. (2015). Does CSR have Different Value Implications for Different Shareholders? Finance Research Letters, 14, 29-35.

8. Dahlsrud, A. (2008). How Corporate Social Responsibility is defined: An Analysis of 37 Definitions. Corporate Social responsibility and Environmental Management, 15, 113.

9. Elkington, J. (1998). Partnerships from cannibals with forks: The triple bottom line of 21st-century business. Environmental Quality Management, 8(1), 37-51.

10. Esses, D; Csete, M. S., \& Nemeth, B. (2021). Sustainability and Digital Transformation in the Visegrad Group of Central European Countries. Sustainability, 13(11), 5833.

11. European Commission. (2019). A Sustainable Europe by 2030. https://ec.europa.eu/commission/publications/reflection-paper-towards-sustainableeurope-2030_sk

12. Fry, R. (2016). Millennials are the largest generation in the U.S. labor force. Pew Research Center. http://www.pewresearch.org/fact-tank/2018/04/11/millennials-largestgeneration-us-labor-force/

13. Havas Worldwide. (2013). Communities and Citizenship: Redesigned for a New World. Prosumer Report, 15.

14. Horoszowski, M. (2016). 64\% of CEOs Are Increasing Investment in Corporate Social Responsibility in 2016-Here's Why. HuffPost. https://www.huffpost.com/entry/64-ofceos-are-increasing_b_9161924

15. Hume, M. (2010). Compassion without action: Examining the young consumers consumption and attitude to sustainable consumption. Journal of World Business, 45(4), 385-394. 
16. Landrum, S. (2017). Millennials driving brands to practice socially responsible marketing. $\quad$ Forbes. https://www.forbes.com/sites/sarahlandrum/2017/03/17/ millennials-driving-brands-to-practice-socially-responsible-marketing/?sh=734e $87 \operatorname{cc} 4990$

17. Lee, N. R., \& Kotler, P. (2015). Social Marketing: Changing Behaviors for Good. (Fifth edition). Los Angeles: SAGE Publications, Inc.

18. Lizbetinova, L., \& Hitka, M. (2016). Selection of Most Suitable Candidates for the Talent Pool in a Furniture Manufacturing Company. Drvna industrija, 67(4), 333-340.

19. Lombardi, C. M., \& Hurlbert, S. H. (2009). Misprescription and misuse of one-tailed tests. Australian Ecology, 34, 447-468.

20. Low, M. P. (2016). Corporate Social Responsibility and the Evolution of Internal Corporate Social Responsibility in 21 st Century. Asian Journal of Social Sciences and Management Studies, 3(1), 56-74.

21. Macfie, B. P., \& Nufrio, P. M. (2006). Applied Statistics for Public Policy. New York: M. E. Sharpe.

22. Majerova, J. (2014). Analysis of Specifics in Buying Behavior of Slovak Customers in Internet Environment. Advances in Social and Behavioral Sciences, 5, 172-178.

23. McGlone, T., Spain, J. W., \& McGlone, V. (2011). Corporate Social Responsibility and the Millennials. Journal of Education for Business, 86(4), 195-200.

24. Moravcikova, D., Krizanova, A., Kliestikova, A., Rypakova, M. (2017). Green Marketing as the Source of the Competitive Advantage of the Business. Sustainability, 9(12), 2218.

25. Moreno, F. M., Lafuente, J. G., Carreón, F. Á., \& Moreno, S. M. (2017). The Characterization of the Millennials and Their Buying Behavior. International Journal of Marketing Studies, 9(5), 135.

26. Nielson. (2015). Green Generation: Millennials Say Sustainability Is a Shopping Priority. Nielsen. http:/www.nielsen.com/us/en/insights/news/2015/green-generationmillennials-saysustainability-is-a-shopping-priority

27. Nielsen. (2018). Was 2018 the Year of the Influential Sustainable Consumer? https://www.nielsen.com/us/en/insights/news/2018/was-2018-the-year-of-theinfluentialsustainable-consumer.html

28. Podhorska, I., Gajanova, L., Kliestikova, J., \& Popescu, G. H. (2017). Analysis of Internally Generated Goodwill Indicators: Case Study of the Slovak Republic. Organizacija, 52(4), 271-285.

29. Rimarcik, M. (2007). Štatistika Pre Prax. Kosice: Marian Rimarcik.

30. Rudominer, R. (2017). Corporate Social Responsibility Matters: Ignore Millennials at Your Peril. HuffPost. https://www.huffpost.com/entry/corporate-socialresponsi_9_b_9155670

31. Ruxton, G. D., \& Neuhauser, M. (2010). When should we use one-tailed hypothesis testing? Methods in Ecology and Evolution, 1, 114-117.

32. Schoolman, E., Shriberg, M., Schwimmer, S., \& Tysman, M. (2016). Green cities and ivory towers: how do higher education sustainability initiatives shape millennials' consumption practices? Journal of Environmental Studies and Sciences, 6(3), 490-502.

33. Taylor, C. (2019). What makes a CSR message resonate with Millennials and Generation_Z? Forbes. https://www.forbes.com/sites/charlesrtaylor/2019/04/30/whatmakes-a-csr-message-resonate-with-millennials-and-generation-z/?sh=736c $81347 \mathrm{fc} 7$ 
34. Wiedmer, T. (2015). Generations Do Differ: Best Practices in Leading Traditionalists, Boomers, and Generations X, Y, and Z. Delta Kappa Gamma Bulletin, 82(1), 51-58.

35. Wood, D. J. (1991). Corporate social performance revisited. Academy of Management Review, 16(4), 691-718. 